\title{
PERAN PERGERAKAN MAHASISWA ISLAM INDONESIA (PMII) KOTA SALATIGA DALAM MENYEBARKAN NILAI-NILAI ISLAM NUSANTARA
}

\author{
Ahmad Wasi' dan Muna Erawati \\ Fakultas Dakwah IAIN Salatiga \\ Jln. Lingkar Selatan Km 02 Pulutan Sidorejo Salatiga \\ Email: ahmadwasiauzzulfa3@gmail.com dan munaerawati@iainsalatiga.ac.id
}

\begin{abstract}
This research is aimed at finding out: 1) PMII roles of Salatiga in 2017 in order to spread values of Islam Nusantara; 2) the inhibing and supporting factors faced by PMII of Salatiga in spreading the values. To get the data needed in this study, the researcher used qualitative descriptive methodology by using library and field research. This result of this study showed that spreading the values of Islam Nusantara consists of two roles named formal and informal roles. While the supporting factors in spreading the values of Islam Nusantara are: a) the number of seniors of PMII became lecturers at the two campuses; b) the large number of Islamic boarding schools around two campuses that have a commissariat of PMII; c) many members who become santri, are affiliated with campus internal organizations; and d) the majority of members are NU backgrounds. while the inhibiting factors are as follows: the number of campuses in Salatiga is relatively few, there are only two Islamic universities around Salatiga, the number of members and administrators are unequal, and the lack of capacity of the committee, and they lulled by the big name of NU.
\end{abstract}

Keyword; Islam Nusantara, Indonesian Islamic Student Movement 


\begin{abstract}
Abstrak
Penelitian ini bertujuan untuk mengetahui Peran PMII Kota Salatiga Tahun 2017 dalam Menyebarkan nilai-nilai Islam Nusantara, untuk mengetahui faktor pendukung dan penghambat yang dihadapi PMII Kota Salatiga Tahun 2017 dalam menyebarkan nilainilai Islam Nusantara. Untuk memperoleh data yang diperlukan dalam penulisan skripsi ini penulis menggunakan Metodologi deskriptif kualitatif dengan pendekatan Lybrary dan Fiel Research. Hasil penelitian menunjukkan penyebaran nilai-nilai Islam Nusantara meliputi dua jenis peran, yaitu peran formal dan peran informal, sedangkan faktor yang menjadi pendukung PMII Kota Salatiga Tahun 2017 dalam menyebarkan nilai-nilai Islam Nusantara diantaranya: banyaknya senior yang menjadi dosen di dua kampus tersebut, banyaknya pondok pesantren yang ada di sekitar dua kampus yang terdapat komisariat dari PMII Kota Salatiga, banyaknya anggota yang menjadi santri, berafiliasi dengan ormawa internal kampus, latar belakang anggota yang mayoritas NU, sedangkan faktor penghambatnya sebagai berikut: jumlah kampus yang ada di Salatiga relatif sedikit, hanya ada dua kampus Islam di sekitar Salatiga, jumlah anggota dan pengurus yang timpang, dan kapasitas dari pengurus, dan terbuai dengan nama besar NU.
\end{abstract}

Kata kunci; Islam Nusantara, Pergerakan Mahasiswa Islam Indonesia

\section{A. PENDAHULUAN}

Organisasi sebagai tempat aktualisasi memiliki arti penting dalam pengembangan diri para anggota. Kebutuhan untuk berinteraksi sosial menjadi alasan mengapa diperlukan berdirinya suatu organsisai. Termasuk dalam hal ini adalah menjaga dan memproduksi nilai-nilai moral masyarakat yang biasanya diemban oleh pendidikan. Pentingnya organisasi akan semakin terlihat jika perubahan zaman yang mengarah pada individualisme disadari secara jujur. Pesatnya perkembanganteknologiinformasi secara alami mengasingkan manusia dari kehidupanya sendiri (Sudarsono, 1989:39).

Konsekuensi dari teknologi informasi yang semakin canggih di zaman milenial ini sehingga semakin mudah pula pahampaham asing masuk dan berkembang di Indonesia. Disinilah peran organisasi seharusnya ikut ambil peran dalam memfilter paham asing tadi, dan ikut terus serta dalam melestarikan atau menjaga nilainilai yang dimiliki bangsa sendiri, apalagi organisasi ekstra kampus, yang harusnya organisasi ektra kampus mempunyai ruang gerak yang lebih luas ketimbang organisasi intra kampus.

Organisasi ekstra kampus merupakan suatu organisasi yang berlatar belakang kemahasiswaan yang berdirinya diluar wewenang kampus. Istilah organisasi ekstra kampus ini muncul pada zaman orde baru yang menerapkan sistem NKK/ BKK (Normalisasi Kehidupan Kampus/ Badan Koordinasi Kemahasiswaan) di dalamseluruh kampus di Indonesia, sehingga mengakibatkan lembaga mahasiswa seperti BEM dan yang lainnya ditiadakan karena dianggap berbahaya oleh pemerintahpada saat itu. Kemudian muncul istilah organisasi ekstra kampus sebagai wujud eksistensi mahasiswa sebagai kaum intelektual yang menyuarakan keadilan bagi rakyat Indonesia yang tertindas pada zaman orde baru (Zainal, 1992: 2-4).

Organisasi ekstra kampus yang sampai saat ini masih terjaga eksistensi 
dan gerakanya salah satunya adalah organisasi ektra kampus yang berwarnakan Islam, organisasi ekstra kampus Islam tadi diantaranya Pergerakan Mahasiwa Islam Indonesia (PMII), Ikatan mahasiswa Muhammadiyah (IMM), dan Himpunan Mahasiswa Islam (HMI).

Sedangkan agama Islam merupakan agama dakwah, yaitu agama yang menegaskan umatnya untuk menyebarkan dan menyiarkan kepada seluruh umat manusia secara arif dan bijaksana. Sebagai agama yang rahmatan lil alamin, Islam dapat menjaminakan terwujudnya kebahagiaan dan kesejahteraan umatnya mana kala ajaran Islam dilaksanakan dengan sungguhsungguh dan benar sebagaimana yang telah dilakukan oleh Nabi Muhammad SAW (Ghofir, 2017:1), rahmatan lil alamin juga bisa diartikan konsep pendekatan terhadap ajaran agama Islam secara proporsional antara Iman, Islam dan Ihsan yang di dalam pola pikir, pola sikap dan pola prilakunya tercermin sifat-sifat selektif, akomodatif, dan integratif (PMII Cabang Kota Salatiga, 2015: 4).

Akan tetapi Islam dewasa ini merupakan agama yang paling sering diperbincangkan. Pemicunya adalah Islam dicurigai berperan penting dibalik berbagai teror dari peristiwa 11 september 2006 di Amerika, Kerusakan di Nigeria, ledakan besardi Hotel J. W Marriot Jakarta, ledakan bom di Kedutaan Australia Jakarta, dan bom bunuh diri di Jembaran Bali. Begitu juga aksi terorisme di Hotel Tajmahal Mombai India yang menewaskan hampir dua ratus jiwa, bom bunuh diri di Masjid Banten, Begitu juga aksi terorisme terjadi di Gereja Kepunton Solo yang menewaskan dua jama'at, penyerangan kantor polisi di Solo merambat perlahan sampai pada pusat kekuasaan yaitu Jakarta dan berbagai aksi terorisme akhir-akhir ini terjadi di Indonesia (Ghofir, 2017:2-3).

Isu tentang agama memang sangatlah sensitif, didukung dengan pesatnya teknologi informasi, permasalahan yang berawal dari permasalahan agama dilempar melalu media-media, alhasil permasalahan intoleransi dan lain sebagainya sangat membesar di akar rumput. Negeri ini memiliki 17.000 pulau dan 1200 suku bangsa yang menunjukkan keragaman yang luar biasa (Romli, 2016:71),Maka dari itu perlu di pertahankan dan di sebar luaskan Islam yang sesuai dengan karakteristik bangsa kita yaitu Islam Nusantara.

Islam Nusantara bukan istilah yang baru, namun kembali populer setelah dilemparkan ke publik oleh Ketua Umum PBNU, KH Said Aqil Siradj dalam pembukaan acara Istigotsah Menyambut Ramadhan dan Pembukaan Munas Alim Ulama NU,Minggu, 14 Juni 2015 di Masjid Istiqlal, Jakarta. Menurut KH Said Aqil Siradj, NU akan terus memperjuangkan dan mengawal model Islam Nusantara. Istilah Islam Nusantara yang ia maksud merujuk pada fakta sejarah penyebaran Islam di wilayah Nusantara yang disebutnya "dengan cara pendekatan budaya, tidak dengan doktrin yang kaku dan keras, Islam Nusantara ini didakwahkan merangkul budaya, melestarikan budaya, menghormati budaya, tidak malah membrangus budaya." KH Said Aqil Siradj juga menambahkan Islam Nusantara memiliki karakter "Islam yang ramah, anti radikal, inklusif dan toleran." Sebagai suatu model, Islam 
Nusantara berbeda dengan apa yang disebutnya sebagai "Islam Arab yang selalu konflik dengan sesama Islam dan perang saudara." Kita pun mafhum, apa yang sedang terjadi di beberapa negara Arab saat ini, seperti Libya, Suriah, Iraq, Mesir, Yaman yang tidak sepi dari kekerasan dan konflik bersaudara, serta yang terbaru bom bunuh diri yang menggoncang Saudi Arabia dan Kuwait (Romli, 2016:18).

Model Islam Nusantara tentunya juga harus dibawa kekalangan mahasiswa, yang notabene kaum intelektual, karena kampus adalah lahan yang strategis, disini harusnya peran Organisasi Mahasiswa bisa dimaksimalkan, khususnya organisasi ektra kampus yang berwarnakan Islam, seperti Pergerakan Mahasiswa Islam Indonesia (PMII) yang notabene lahir dari ORMAS Islam terbesar di Indonesia yakni NU.

PMII didirikan pada 17 April 1960, bertempat di Surabaya. Untuk selanjutnya melakukan pengkaderan di seluruh Indonesia, PMII dalam pandangan keagaman adalah Ahlusunna Wal Jamaah yang selaras dengan pandangan Nahdlatul Ulama sebagai induk yang melahirkannya. PMII memiliki komitmen dalam mempertahankan Negara Kesatuan Republik Indonesia dan memelihara tradisi lokal bangsa Indonesia.

PMII sebagai komponen gerakan yang berafiliasi secara emosional dan kultural dengan gerakan Nahdlatul Ulama menjadi strategis dan signifikan menjadi pionir Gerakan Moderasi Islam di Indonesia, khususnya pada dinamika gerakan kaum muda. Karena pada tingkat diskursus wacana, penguatan masyarakat dan aksentuasi kepentinganya selalu dibangun dengan spirit keislaman, kemasyarakatan dan kebangsaan (PMII Cabang Kota Salatiga, 2015: 1-2).

\section{B. METODE PENELITIAN}

Jenis penelitian ini termasuk penelitian lapangan (Field Research) karena informasi data yang diperlukan digali serta dikumpulkan dari lapangan. Adapun penelitian ini bersifat deskriptif kualitatif, yaitu mengungkap fakta, keadaan, fenomena, variabel dan keadaan yang terjadi saat penelitian berjalan dan menyuguhkan apa adanya.

Penelitian ini akan difokuskan di Kesekretariatan Pengurus Cabang PMII Kota Salatiga, dikarenakan mudah dijangkau karena tidak jauh dari kampus Institut Agama Islam Negeri (IAIN) Salatiga yang mana adalah kampus dari peneliti dan tidak jauh dari pusat Pemerintahan Kota Salatiga.

Adapun sumber data yang dikumpulkan oleh peneliti adalah dari hasil wawancara dengan Pengurus Cabang PMII Kota Salatiga periode 2017, Alumni PMII Kota Salatiga dan Anggota PMII Kota Salatiga, serta dokumentasi yang menyangkut penelitian tersebut.

\section{HASIL DAN PEMBAHASAN}

Peran Pergerakan Mahasiswa Islam Indonesia Kota Salatiga Tahun 2017 dalam Menyebarkan Nilai-nilai Islam NusantaraKota Salatiga diantaranya nilai kebudayaan, nilai cinta tanah air, nilai tawassuth atau tengah-tengah, nilai tawazun atau seimbang, nilai al-i'tidal atau adil, dan nilai tasamuh atau toleransi.

Dalam penyebaran nilai-nilai Islam Nusantara, PMII Kota Salatiga tentunya 
melibatkan beberapa elemen diluar PMII, jadi tidak hanya melakukan pergerakan sendirian, sehingga peran yang dilakukan oleh PMII dapat lebih maksimal, di dalam perannya PMII Kota Salatiga saling bersinergi dengan beberapa elemen, sebagai berikut : (1) dosen yang beridiologikan sama, yakni dosen yang merupakan alumni PMII dan orang NU; (2) pondok Pesantren yang ada di sekitar Kota Salatiga; (3) Kyai dan Ustad yang menjadi pengajar di Pondok Pesantren yang ada di sekitar Kota Salatiga; dan (4) Ormawa kampus

Penulis menilai antara PMII dengan elemen-elemen diatas dapat terwujudnya sinergisitas karena kesamaan Ideologi, kesamaan kultur dan kesamaa visi.

Peran informal yang yakni meliputi produk hukum dan kurikulum kaderisasi formal PMII, peran penyebaran nilai-nilai Islam Nusantara oleh PMII Kota Salatiga yang bersinergi dengan pihak-pihak yang sudah disebutkan di atas.

Sedangkan peran informal dari PMII Kota Salatiga tidak nampak jelas didalam proses penyebarannya.Berikut bentuk senirgisitas PMII dengan elemen-elemen diatas, sebagai berikut :

1. Dosen melakukan proses penyebaran melalui penyampaian saat kegiatan belajar mengajar, dengan menyelipkan nilai-nilai Islam Nusantara, melalui teladan sikap dan lain sebagainya, dosen yang dimaksut memposisikan diri sebagai orang yang beridiologikan sama dengan PMII dan memposisikan diri sebagai alumni atau senior PMII.

2. Kyai dan Pondok Pesantren tentunya dalam kehidupan di Pondok dan saat belajar mengajar tentunya juga terkandung nilai-nilai Islam Nusantara, karena memang kultur Pondok Pesantren dan PMII tidak bisa dilepaskan dari Islam Nusantara khususnya di Salatiga.

3. Sedangkan Ormawa kampus melakukan proses penyebaran melalui penyelenggaraan kegiatan-kegiatan yang ada di kampus, yang disitu diselipkan nilai-nilai Islam Nusantara, baik dari bentuk kegiatan, isi kegiatan, yang mengisi kegiatan dan lain sebagainya, tentunya ormawa yang posisi-posisi strategisnya diisi oleh kader-kader PMII Kota Salatiga.

Selanjutnya penulis mempolakan nilai-nilai Islam Nusantara yang disebarkan oleh PMII Kota Salatiga meliputi tiga nilai, yaitu penyebaran nilai kebudayaan, penyebaran nilai kebangsaan atau cinta tanah air, dan penyebaran nilai ASWAJA, dan menggolongkan dalam peran formal.

Adapun hasil dari wawancara tersebut yang termasuk dalam cara penyebaran nilai kebudayaan yang dilakukan PMII Kota salatiga adalah melalui cara yaitu : (1) melakukan ziarah kubur; (2) merawat tradisi dari NU; (3) tabayun kepada kiai; (4) membaca kitab; dam (5) bermasyarakat.

Selain nilai kebudayaan, juga terdapat nilai cinta tanah air atau kebangsaan dari hasil wawancara peneliti dapat menggambarkan cara penyebarannya dengan cara : (1) melalui produk hukum PMII; (2) melalui materi dalam kaderisasi formal; dan (3) melalui diskusi.

Selanjutnya terdapat nilai Aswaja,berikut hasil wawancara antara 
lain yaitu : (1) melalui kaderisasi formal; (2) melalui perilaku keseharian dengan anggota; dan (3) melalui perilaku keseharian dengan lingkungan yang ada di Kota Salatiga.

Sedangkan faktor pendukung dan penghambat Pergerakan Mahasiswa Islam Indonesia Kota Salatiga Tahun 2017 dalam Menyebarkan Nilai-Nilai Islam Nusantara antara lain:

\section{Faktor Pendukung}

Dalam suatu proses, tentunya terdapat hal-hal yang menjadi pendukung suatu proses tadi, dalam konteks ini penulis melakukan wawancara dengan tujuan mengetahui apa saja faktor pendukung PMII Kota Salatiga dalam menyebarkan nilai-nilai Islam Nusantara, setelah penulis melakukan wawancara dengan naraumber, penulis dapat menuliskan faktor-faktor pendukung yaitu : (1) memiliki dua komisariat yang berada di kampus Islam; (2)banyaknya senior yang menjadi dosen di IAIN Salatiga dan UNU Susukan; (3) banyaknya pondok pesantren yang ada di sekitar IAIN Salatiga dan UNU Susukan; (4) banyaknya anggota yang menjadi santri; (5) berafiliasi dengan ormawa internal kampus; dan (6) latar belakang anggota yang mayoritas NU

\section{Faktor Penghambat}

Tentunya juga terdapat faktor penghambat, penulis menemukan beberapa faktor penghambat, setelah melakukan wawancara dengan narasumber yang sama, berikut ini faktor-faktor penghambat PMII Kota Salatiga dalam menyebarkan nilai-nilai Islam Nusantara yaitu : (1) jumlah kampus yang ada di Salatiga relatif sedikit; (2) hanya ada dua kampus Islam di Salatiga; (3) jumlah anggota dan pengurus yang timpang; (4) sistem pendidikan yang seolah-olah mengekang mahasiswa; (5) banyak sekali mahasiswa yang hedon, apatis, egois di zaman milenial ini; (6) banyaknya perbedaan pemikiran, dan kapasitas dari pengurus; dan (7) terbuai dengan nama besar NU

\section{SIMPULAN}

Peran informal yang di lakukan PMII Kota Salatiga dalam menyebarkan nilainilai Islam Nusantara yaitu melalui produk hukum PMII, dan bersinergi dengan pihakpihak yang sudah disebutkan tadi.

Peran formal yang di lakukan PMII Kota Salatiga dalam menyebarkan Nilainilai Islam Nusantara yaitu melalui agenda PMII Kota Salatiga, program kerja bidang agama, dan hal-hal yang disampaikan saat wawancara dengan narasumber di atas.

Adapun nilai-nilai yang disebarkan oleh PMII Kota Salatiga meliputi nilai-nilai yaitu : (1) penyebaran nilai kebudayaan; (2) penyebaran nilai kebangsaan atau cinta tanah air; dan (3) penyebaran nilai ASWAJA, untuk nilai-nilai ASWAJA dalam terjemahan ber PMII melingkupi $4 \mathrm{~T}$ (Tawazun, Tawasuth, Tasamuh dan Ta-Adl).

Dari total delapan nilai-nilai Islam Nusantara, terdapat dua nilai yang belum disebarkan oleh PMII Kota Salatiga, hal tersebut mungkin nantinya dapat menjadi koreksi atau menjadi evaluasi bagi PC PMII Kota Salatiga.

Faktor Pendukung dan Penghambat Pergerakan Mahasiswa Islam Indonesia Kota Salatiga Tahun 2017 Dalam Menyebarkan Nilai-Nilai Islam Nusantara. 
Adapun faktor-faktor yang menjadi pendukung dalam PMII Kota Salatiga melakukan peranya menyebarkan nilainilai Islam Nusantara, dapat kita lihat ebagai berikut : (1) memiliki dua komisariat yang berada di kampus Islam; (2) banyaknya senior yang menjadi dosen di dua kampus tersebut; (3) banyaknya pondok pesantren yang ada di sekitar dua kampus tersebut; (4) banyaknya anggota yang menjadi santri; (5) berafiliasi dengan ormawa internal kampus; dan (6) latar belakang anggota yang mayoritas NU.

Adapun faktor-faktor penghambat dalam PMII Kota Salatiga melakukan peranya menyebarkan nilai-nilai Islam Nusantara, dapat kita lihat ebagai berikut : (1) jumlah kampus yang ada di Salatiga relatif sedikit; (2) hanya ada dua kampus Islam di Salatiga; (3) jumlah anggota dan pengurus yang timpang; (4) sistem pendidikan yang seolah-olah mengekang mahasiswa; (5) banyak sekali mahasiswa yang hedon, apatis, egois di zaman milenial (6) banyaknya perbedaan pemikiran, kapasitas dari pengurus dan (7) terbuai dengan nama besar NU.

\section{DAFTAR PUSTAKA}

Arikunto, Suharsimi. (2005). Prosedur Penelitian Suatu Pendekatan Praktek. Jakarta: Rineka Cipta.

Bahdin Nur Tanjung dan Ardial. (2005). Pedoman Penulisan Karya Ilmiah. Jakarta: Kencana Perenada Grup.

Ghofir, Jamal. (2017). Nilai Toleransi Dalam Dakwah Nabi Muhammad SAW. Yogyakarta: Dialektika.

Isna Mansur. (2001). Diskursus Pendidikan Islam. Yogyakarta: Global Pustaka Utama.

Maarif Syamsul. (2007). Revitalisasi Pendidikan Islam. Yogyakarta: Graha Ilmu.

Moleong, Lexy J. (2005). Metodologi Penelitian Kualitatif. Jakarta: Radja Grasindo Persada.

Nofia Lestiana. (2013). Peran Organisasi Pergerakan Mahasiswa Islam Indonesia (PMII) Cabang Kota Semarang dalam Meningkatkan Kepemimpinan Mahasiswa. Skripsi. Fakultas Ilmu Sosial Universitas Negeri Semarang. hlm. 91-97.

Nugraha Munandar. (2017). Cuma Catatan Kaderisasi. Yogyakarta: Dialektika.

NurHidayati.(2011).PeranOrganisasiEkstra Kampus Dalam Penegembangan Intelektual, Moral, Sosial Bagi Mahasiswa UIN Sunan Kalijaga Yogyakarta. Skripsi. Fakultas Ilmu Tarbiyah dan Keguruan Universitas Islam Negeri Sunan Kalijaga. hlm. 86-100.

PB PMII. (2017). Konstitusi \& Kompilasi Produk Hukum PMII. Malang: Intelegensia Media. 
PMII Cabang Kota Salatiga. (2015). MAPABA (Masa Penerimaan Anggota Baru). Salatiga: PMII Cabang Kota Salatiga.

Purwadaminta W.J.S. (1999). Kamus Umum bahasa Indonesia .Jakarta; Balai Pustaka.

RomliMuhamda Guntur, dkk. (2016). Islam Kita, Islam Nusantara. Ciputat: Ciputat School.

Sudarsono.(1989).Etika Tentang Kenakalan Remaja. Jakarta: Rineka cipta. Cet. I

Sugiyono.(2013). Metodologi Penelitian, Kuantitatif, Kualitatif, dan RED. Bandung : Alfabeta. Cet. 18.

Sunyoto Agus. (2017). Atlas Wali Songo. Tangerang: Pustaka Iman dan LESBUMI PBNU. Cet. 7

Syaefuddin Ahrom Al Ayubbi. (2015).Peran Organisasi Ektsra Kampus Dalam Meningkatkan Interaksi Sosial dan Kepemimpinan Mahasiswa, Skripsi. Fakultas Ilmu Tarbiyah dan Keguruan Universitas Islam Negeri Sunan Kalijaga tahun. hlm. 115-116.

Thoha M. Chabib. (1996). Kapita Selekta Pendidikan Islam. Yogyakarta: Pustaka Pelajar. Cet. 1.

Zainal, C. Ariangga.(1992). Peran Forum Komunikasi Mahasiswa Universitas Indonesia Dalam Pembentukan Senat Mahasiswa Universitas Indonesia 1986-1992. Skripsi. Universitas Indonesia Fakultas Ilmu Budaya. hlm2-4.

(http:/ / salatigapmii.blogspot.com. diakses pada 14 Februari 2018). 